\title{
Diversity of social wasps (Hymenoptera, Vespidae, Polistinae) in three fragments of semideciduous seasonal forest in the northwest of São Paulo State, Brazil
}

\author{
Bruno Gomes $^{1} \&$ Fernando B. Noll ${ }^{1}$
}

'Laboratório de Vespas Sociais, Departamento de Zoologia e Botânica, Universidade Estadual Paulista “Júlio de Mesquita Filho"; Rua Cristóvão Colombo, 2265; 15054-000 São José do Rio Preto-SP, Brazil. biologia_unesp@yahoo.com.br; noll@ibilce.unesp.br

\begin{abstract}
Diversity of social wasps (Hymenoptera, Vespidae, Polistinae) in three fragments of semideciduous seasonal forest in the northwest of São Paulo State, Brazil. Human exploitation of the forest in the northwest of São Paulo State has generated enormous fragmentation of that forest. Such disturbance has reduced the populations of insects in general. This work was a survey of social wasps (Hymenoptera, Vespidae; Polistinae) in three areas in different stages of regeneration: Paulo de Faria - SP (435 ha), Pindorama - SP (128 ha) and Neves Paulista - SP (1 ha). These three areas were chosen for comparative purposes. To capture the wasps, it was used: active collecting with attractant liquid (solution of water, salt and sugar) with the aid of a dorsal spray bag. During the period from July to December 2006, 414 social wasps were collected in Paulo de Faria, constituting seven species belonging to four genera; 111 social wasps were collected in Pindorama, constituting six species belonging to four genera, and 129 social wasps were collected in Neves Paulista constituting 12 species belonging to seven genera. In order to compare these three areas ecological indexes were calculated. Neves Paulista had the greatest diversity, and Paulo de Faria presented greater abundance. These factors were probably caused by neighboring areas and ecological corridors, which were limited in Paulo de Faria and Pindorama.
\end{abstract}

KEYWORDS. Diversity; Hymenoptera; Polistinae; Vespidae.

RESUMO. Diversidade de vespas sociais (Hymenoptera, Vespidae, Polistinae) em três fragmentos de floresta estacional semidecidual no noroeste do Estado de São Paulo, Brasil. A ação antrópica no noroeste do Estado de São Paulo tem gerado grande fragmentação florestal. Tais perturbações reduziram as populações de insetos em geral. Neste trabalho foi realizado um levantamento de vespas sociais (Hymenoptera, Vespidae; Polistinae) em três áreas em diferentes estágios de regeneração, em Paulo de Faria - SP (435 ha), Pindorama (128 ha) e em Neves Paulista (1 ha), escolhidas para fins comparativos. Para capturar as vespas, foi utilizada: coleta ativa com utilização de líquido atrativo (solução de água, sal e açúcar) com auxílio de um borrifador dorsal de alavanca. Durante o período de Julho a Dezembro de 2006 foram capturados 414 vespídeos sociais em Paulo de Faria, sendo estes distribuídos em sete espécies pertencentes a quatro gêneros; em Pindorama, foram coletadas 111 vespas sociais distribuídos em seis espécies pertencentes a quatro gêneros, e em Neves Paulista, um total de 129 vespídeos sociais distribuídos em 12 espécies pertencentes a sete gêneros. A fim de comparar as três áreas foram utilizados índices ecológicos. A área de Neves Paulista obteve a maior diversidade e Paulo de Faria a maior abundância de vespas. Tais fatores provavelmente foram causados pela influência das áreas vizinhas e pelos corredores ecológicos, que eram limitados na área de Paulo de Faria e Pindorama.

PALAVRAS-CHAVE. Diversidade; Hymenoptera; Polistinae; Vespidae.

Tropical forests are large areas that encompass the most diverse and complex ecosystems in the world, sheltering a high diversity of the world biota (Tomasetto 2003). Over time these large areas have been transformed into small fragments due to the expansion of agricultural areas. These resources, that a few decades ago seemed to be unlimited, are today finite and vulnerable (Whitmore 1990).

Forest fragments are defined as continuous areas of native vegetation interrupted by human action. The most common examples of such action would be pastures, agricultural cultures, roads, reforesting, mines, villages, among others, that may reduce the flow of animals, pollen and seeds (Viana \& Tabanez 1996).

The most well-preserved areas in Brazil are located mainly in the Amazon area, even though it is being subject to a continuous area diminution. This is not different from the State of São Paulo, where deforesting has resulted in the destruction of about eighty per cent of the native vegetation, mostly caused by the economic model adopted in the past (Ministerio do Meio Ambiente 2006).

Social wasps are an important group of neotropical social insects, but neglected. Their social organization, notably expressed in the variation of nest architecture and workers aggressiveness in defense of their colonies, attracts both the general public and particularly entomologists.

The Polistinae is a subfamily of Vespidae, encompassing 25 genera and more than 900 species, with most species in the tropics and subtropics (Richards 1971, 1978; Carpenter et al. 1996). In Brazilian Amazonia, 20 genera and 200 species are recorded, representing approximately $2 / 3$ of the Brazilian fauna (Silveira 2002).

As insect predators, social wasps play an important role in terrestrial food chains (Carpenter \& Marques 2001). Several methods are employed by wasps to locate and collect different 
sorts of materials necessary to colony maintenance (Richter 2000). Carbohydrates are found mainly by olfaction and living prey by visual stimuli (Richter 2000). Wasps feed themselves and their larvae on prey body liquids, nectar, honey insect exudates, fruits and other sugary products, such as honeydew (Richter 2000). In the Epiponini, Agelaia Lepeletier, 1836 and Angiopolybia Araújo, 1946 are common consumers of dead animals (O’Donnell 1995; Silveira et al. 2005). Here we compare three fragments of semideciduous seasonal forest from the northwest of São Paulo State, in different stages of regeneration, with the purpose of comparing diversity and richness of social wasps.

\section{MATERIALAND METHODS}

Study areas. We used three different areas regarding size and conservation level in the northwest of São Paulo. The largest area (435 ha) is located in the municipality of Paulo de Faria (S 1958' W 49 31' / S 1955' W 49 30'). The second largest area (128 ha) is located in the municipality of Pindorama ( $\mathrm{S}$ $21^{\circ} 13^{\prime} \mathrm{W} 48^{\circ} 55^{\prime} / \mathrm{S} 21^{\circ} 13^{\prime} \mathrm{W} 48^{\circ} 56^{\prime}$ ). The smallest area ( $1 \mathrm{ha}$ ) is located in the municipality of Neves Paulista (S 20 $49^{\prime} \mathrm{O} 49^{\circ} 34^{\prime}$ /S $\left.20^{\circ} 50^{\prime} \mathrm{O} 49^{\circ} 34^{\prime}\right)$.

Methods. We carried out monthly collections in the period from July to December of 2006, using a methodology based on active collection using an attractive liquid (Noll \& Gomes, in press). This methodology uses a $200 \mathrm{~m}$ transect in the vegetation in which is sprayed a solution of sucrose $(1: 5$, commercial sugar: water) with $2 \mathrm{~cm}^{3}$ of salt for each liter of solution. With the aid of a costal sprayer, about $500 \mathrm{ml}$ of solution was sprayed in each point of collection, in an area of approximately $3 \mathrm{~m}^{2}$. Ten points were defined, $20 \mathrm{~m}$ distant from each other along the transect. The attracted insects were captured with an entomological net, in four periods of the day from 10:00 to 17:00h, during 5 minutes at each collecting point, with an interval of approximately 1:30h. Collections were carried out fortnightly and after each spraying the temperature and relative humidity were measured. The specimens collected were identified and deposited in Hymenoptera Collection from the Department of Zoology and Botany, IBILCE - UNESP.

Ecological indices. For the comparison of the three areas we used the rarefaction curve model of Hulbert. We used as indices of diversity that of Shannon-Wiener $\left(\mathrm{H}^{\prime}\right)$, the Pielou index of equitability, and the Berger-Parker index of dominance using the software PAST, v. 1.37 (Hammer et al. 2005). Also, in order to evaluate the similarity between sampled areas we used the coefficients of Jaccard and of Bray-Curtis using the software PAST, v. 1.37 (Hammer et al. 2005).

\section{RESULTS AND DISCUSSION}

From July to December of 2006414 social wasps were collected in the forest fragment of Paulo de Faria, constituting four genera and seven species; in Pindorama 111 social wasps were collected, constituting four genera and six species and in Neves Paulista 129 social wasps were collected, constituting seven genera and 12 species (Table I). Neves Paulista was the area with the largest diversity of wasps collected (Table II), and the number of wasps was similar to other previous surveys (Tables II-III) in the State of Bahia by Silva-Pereira \& Santos (2006) in Campos Rupestres and by Aguiar \& Santos (2007) in Caatinga. The surveys in Paulo de Faria and Pindorama had results close to those found by Santos et al. (2007) in the State of Bahia, and in the Mangue area in the State of Pará (Silveira et al. 2005, but only necrophagous wasps were collected).

Based on the rarefaction curve (Fig. 1) we see that Neves Paulista presented the largest number of species collected compared with the other areas, however it did not present a large abundance, as in Paulo de Faria; Polistes versicolor (Olivier, 1791), Mischocyttarus rotundicollis (Cameron, 1912), Agelaia pallipes (Olivier, 1791), Polybia ignobilis (Haliday, 1836) and $P$. jurinei de Saussure, 1854 were the species common in the three areas studied and Agelaia was the most abundant genus (Table I). All the species collected in the three areas were collected in Neves Paulista with the exception of Mischocyttarus cerberus Ducke, 1918 and A. vicina (de Saussure, 1854). In the latter, it happens perhaps because this species needs large spaces for their nests, which are in holes in large trees (Zucchi et al. 1995), not found in this area. Brachygastra lecheguana (Latreille, 1824), Metapolybia cingulata (Fabricius, 1804), Polybia paulista (von Ihering, 1896), P. sericea (Oliver, 1791), P. occidentalis (Olivier, 1791), P. ruficeps Schrottky, 1902 and Protonectarina sylveirae (de Saussure, 1854) were found only in Neves Paulista. Polybia commonly nests in urban constructions (Richards 1978). Metapolybia cingulata generally builds nests in the borders of forests (Richards 1971) and the transects were a few meters from the border. Brachygastra lecheguana is also a wasp that tends to nest in open areas, in bushy vegetation close to the ground (Richards 1971).

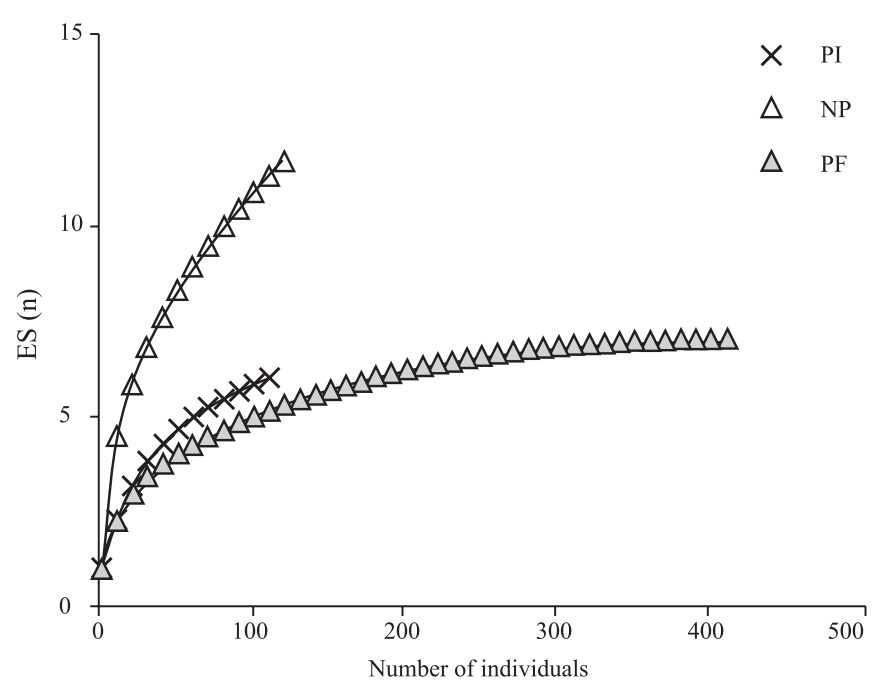

Fig. 1. Rarefaction curve for the wasps collected in the three studied areas: (PF) Paulo de Faria, (PI) Pindorama and (NP) Neves Paulista. 


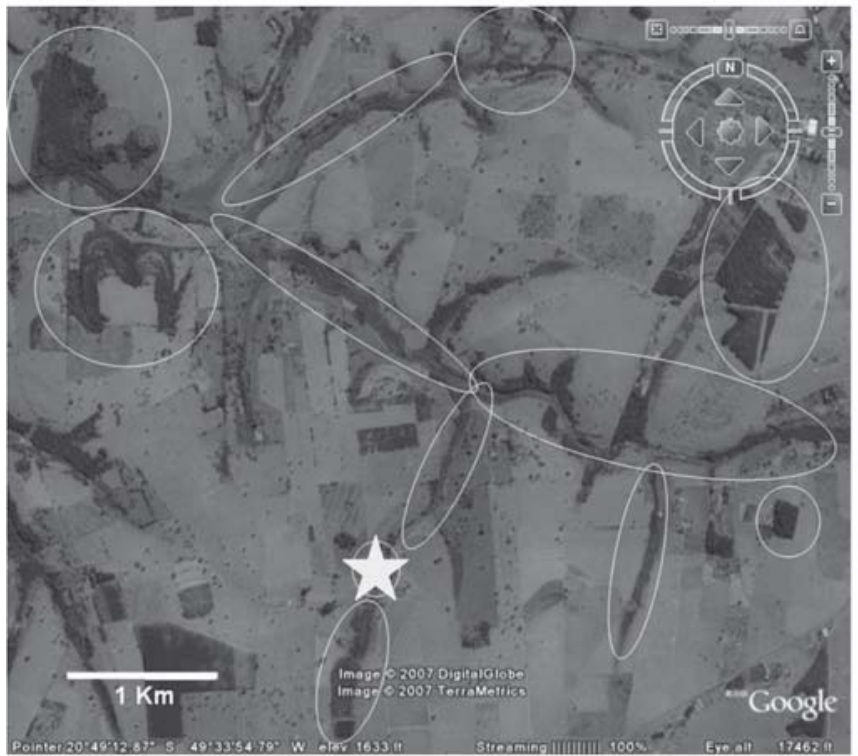

Fig. 2. Satellite image indicating Neves Paulista (star) and adjacent areas (ellipses).

Regarding the Shannon-Wiener index $\left(\mathrm{H}^{\prime}\right)$ Neves Paulista presented the larger number of less abundant species, followed by Pindorama and finally Paulo de Faria (Table II). Neves Paulista thus presented a higher diversity of wasps, despite possessing a smaller area and being more degraded. However, unlike Paulo de Faria and Pindorama, Neves Paulista is not isolated from other fragments, being connected by several natural ecological corridors (Fig. 2). Possibly the isolation of Paulo de Faria and Pindorama complicates the transition of wasps from a fragment to another, because the flight range of some polistines is around $150 \mathrm{~m}$ (Prezoto \& Gobbi 2005).

Table I. Polistinae collected in Paulo de Faria, Pindorama and Neves Paulista during the entire collection period.

\begin{tabular}{|c|c|c|c|}
\hline Species & $\begin{array}{l}\text { Paulo de } \\
\text { Faria }\end{array}$ & Pindorama & $\begin{array}{l}\text { Neves } \\
\text { Paulista }\end{array}$ \\
\hline Agelaia pallipes (Olivier, 1791) & $4.0 \%$ & $86.0 \%$ & $48.0 \%$ \\
\hline A. vicina (de Saussure, 1854) & $85.0 \%$ & $1.0 \%$ & $0.0 \%$ \\
\hline $\begin{array}{l}\text { Protonectarina sylveirae (de } \\
\text { Saussure, 1854) }\end{array}$ & $0.0 \%$ & $0.0 \%$ & $1.0 \%$ \\
\hline Polybia occidentalis (Olivier, 1791) & $0.0 \%$ & $0.0 \%$ & $18.0 \%$ \\
\hline P. paulista (von Ihering, 1896) & $0.0 \%$ & $0.0 \%$ & $5.0 \%$ \\
\hline P. jurinei de Saussure, 1854 & $8.0 \%$ & $4.5 \%$ & $17.0 \%$ \\
\hline P. ignobilis (Haliday, 1836) & $0.5 \%$ & $3.0 \%$ & $2.0 \%$ \\
\hline P. sericea (Oliver, 1791$)$ & $0.0 \%$ & $0.0 \%$ & $1.0 \%$ \\
\hline P. ruficeps Schrottky, 1902 & $0.0 \%$ & $0.0 \%$ & $1.0 \%$ \\
\hline $\begin{array}{l}\text { Metapolybia cingulata (Fabricius, } \\
\text { 1804) }\end{array}$ & $0.0 \%$ & $0.0 \%$ & $1.0 \%$ \\
\hline $\begin{array}{l}\text { Brachygastra lecheguana (Latreille } \\
1824 \text { ) }\end{array}$ & $0.0 \%$ & $0.0 \%$ & $1.0 \%$ \\
\hline $\begin{array}{l}\text { Mischocyttarus rotundicollis } \\
\text { (Cameron, 1912) }\end{array}$ & $0.5 \%$ & $4.5 \%$ & $1.0 \%$ \\
\hline M. cerberus Ducke, 1918 & $1.0 \%$ & $0 \%$ & $0 \%$ \\
\hline Polistes versicolor (Olivier, 1791) & $1.0 \%$ & $1.0 \%$ & $4.0 \%$ \\
\hline
\end{tabular}

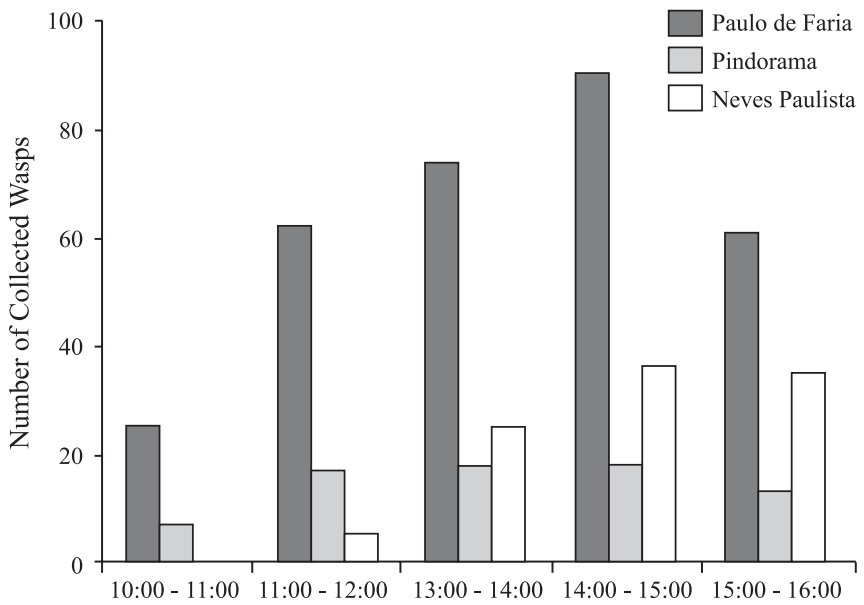

Fig. 3. Number of wasps collected in different periods of the day in the three studied areas.

Regarding the Pielou index the most heterogeneous area in terms of distribution of wasps was Neves Paulista, followed by Pindorama and Paulo de Faria (Table II). As a consequence of these values, the largest indices of Berger-Parker, based in the proportional importance of the most abundant species, showed that these two areas presented dominant species (Table II), especially from the genus Agelaia (Table I). Regarding the index of similarity based on the Jaccard coefficient, Pindorama and Paulo de Faria showed more similarity $(85.11 \%)$ in comparison to Neves Paulista (35.71\% to Paulo de Faria and $38.46 \%$ to Pindorama, respectively). Regarding the Bray-Curtis index, the most similar areas were Pindorama and Neves Paulista (60.0\%) and Paulo de Faria area was $20 \%$ less similar than the other two areas (11.05\% to Pindorama and $16.94 \%$ to Neves Paulista, respectively). These indexes indicate that these large areas were similar regarding abundance of wasps and the smaller area presented a larger diversity.

A progression in the total number of individuals collected was observed from 10:00 h (Fig. 3), with the period of highest abundance between 13:00 and 15:00 h, and afterwards a continuous decrease in the total of individuals, probably due to decrease of luminosity.

Previous surveys have focused on the Cerrado (Souza \& Prezoto 2006; Elpino-Campos et al. 2007), Amazon Forest (Silveira 2002), Atlantic Forest (Hermes \& Köhler 2006; Santos, et al. 2007), Caatinga (Aguiar \& Santos 2007), Mangue (Santos et al. 2007), Restinga (Santos et al. 2007) and Campos Rupestres (Silva-Pereira \& Santos 2006). In the northwest of São Paulo State there has been practically no survey of Polistinae before,

Table II. Indices of diversity, distribution and dominance of species in the studied areas of Paulo de Faria, Pindorama and Neves Paulista.

\begin{tabular}{lccc}
\hline Indices & Paulo de Faria & Pindorama & Neves Paulista \\
\hline Shannon_H' & 0.56 & 0.59 & 1.59 \\
Equitability_J' & 0.31 & 0.33 & 0.64 \\
Berger-Parker & 0.86 & 0.86 & 0.48 \\
\hline
\end{tabular}


Table III. Comparison among the total number of species in the present work $(*)$ and other surveys from the literature.

\begin{tabular}{lc}
\hline Surveys & N. of species \\
\hline Silveira 2002 (Amazon Forest) & 79 \\
Souza \& Prezoto 2006 (Cerrado and Semideciduous & 38 \\
Forest) & \\
Elpino-Santos et al. 2007 (Cerrado) & 29 \\
Hermes \& Köhler 2006 (Atlantic Forest) & 25 \\
Santos et al. 2007 (Atlantic Forest) & 18 \\
Santos et al. 2007 (Restinga - Sandbank) & 16 \\
Aguiar \& Santos 2007 (Caatinga) & 13 \\
*Neves Paulista (Semideciduous Forest) & 12 \\
Silva-Pereira \& Santos 2006 (Campos Rupestres) & 11 \\
Santos et al. 2007 (Mangue) & 8 \\
*Paulo de Faria (Semideciduous Forest) & 7 \\
Silveira et al. 2005 (Amazon Forest) & 6 \\
*Pindorama (Semideciduous Forest) & 6 \\
\hline
\end{tabular}

so this study is a necessary contribution to the knowledge of the remaining diversity of the fragments of native forests in this area.

Acknowledgments. We wish to thank FAPESP (07/08633-1) and CNPq (300312/2004-0 e 479790/2004-3) for financial support and two anonymous reviewers for their important suggestions and corrections and along the manuscript. The specimens were collected under permits from IBAMA (10739-1).

\section{REFERENCES}

Aguiar, C. M. L. \& G. M. M. Santos. 2007. Compartilhamento de recursos florais por vespas sociais (Hymenoptera:Vespidae) e abelhas (Hymenoptera: Apoidea) em uma área de Caatinga. Neotropical Entomology 36: 836-842.

Carpenter, J. M.; J. W. Wenzel \& J. Kojima. 1996. Synonymy of the Genus Occipitalia Richards, 1978, with Clypearia de Saussure, 1854 (Hymenoptera: Vespidae; Polistinae, Epiponini). Journal Hymenoptera Research 5: 157-165.

Carpenter, J. M. \& O. M. Marques. 2001. Contribuição ao estudo dos vespídios do Brasil (Insecta, Hymenoptera, Vespoidea, Vespidae) [CD-ROM]. Cruz das Almas - BA, Brasil. Universidade Federal da Bahia, Escola de Agronomia, Departamento de Fitotecnia / Mestrado em Ciências Agrárias. Série Publicações Digitais, 2.

Elpino-Campos, A.; K. Del-Claro \& F. Prezoto. 2007. Diversity of social wasps (Hymenoptera: Vespidae) in Cerrado fragments of Uberlândia, Minas Gerais State, Brazil. Neotropical Entomology 36: 685-692.
Hammer, O.; D. A. T. Harper \& P. D. Ryan. 2005. Past: paleontological statistics software package for education and data analysis. Versão 1.37. Palaeontologica Electronica 4: 1-9.

Hermes, M. G. \& A. Köhler. 2006. The flower-visiting social wasps (Hymenoptera, Vespidae, Polistinae) in two areas of Rio Grande do Sul State, southern Brazil. Revista Brasileira de Entomologia 50: $268-274$.

Ministério do Meio Ambiente. 2006. Relatório de Qualidade Ambiental do Estado de São Paulo. Lei 9.509/97. 498 p.

Noll, F. B. \& Gomes, B. in press. An improved bait method for collecting Hymenoptera, especially social wasps (Vespidae; Polistinae). Neotropical Entomology.

O’Donnell, S. 1995. Necrophagy by Neotropical Swarm-Founding Wasps (Hymenoptera: Vespidae, Epiponini). Biotropica 27: 133-136.

Prezoto, F. \& N. Gobbi. 2005. Flight Range Extension in Polistes simillimus Zikán, 1951 (Hymenoptera, Vespidae). Brazilian Archives of Biology and Technology 48: 947-950.

Richards, O. W. 1971. The biology of the social wasps (Hymenoptera: Vespidae). Biological Reviews. 46: 483-528.

Richards, O. W. 1978. The social wasps of the Americas excluding the Vespinae. London. British Museum (Natural History). 580 p.

Richter, M. R. 2000. Social wasp (Hymenoptera: Vespidae) foraging behavior. Annual Review of Entomology 45: 121-150.

Santos, G. M. M.; C. C. B. Filho; J. J. Resende; J. D. Cruz \& O. M. Marques. 2007. Diversity and community structures of social wasps (Hymenoptera: Vespidae) in three ecosystems in Itaparica Island, Bahia State, Brazil. Neotropical Entomology 36: 180-185.

Silva-Pereira, V. \& G. M. M. Santos. 2006. Diversity in bee (Hymenoptera: Apoidea) and social wasp (Hymenoptera: Vespidae, Polistinae) community in "campos rupestres", Bahia, Brazil. Neotropical Entomology 35: 163-174.

Silveira, O. T. 2002. Surveying neotropical social wasps. An evaluation of methods in the "Ferreira Penna" Research Station (ECFPn), in Caxiuanã, PA, Brazil (Hymenoptera, Vespidae, Polistinae). Papéis Avulsos de Zoologia 42: 299-323.

Silveira, O. T.; M. C. Esposito; J. N. Santos \& F. E. Gemaque. 2005. Social Wasps and bees captured in carrion traps in a rainforest in Brazil. Entomogical Science 8: 33-39.

Souza, M. M. \& F. Prezoto. 2006. Diversity of social wasps (Hymenoptera: Vespidae) in semideciduos Forest and cerrado (savanna) regions in Brazil. Sociobiology 47: 135-147.

Tomasetto, F. 2003. Composição florística e estrutura do componente arbóreo de um trecho de Floresta Estacional Semidecidual na Estação Ecológica de Paulo de Faria - SP. (Dissertação de Mestrado). Rio Claro, UNESP. 133 p.

Viana, V. M. \& A. J. Tabanez. 1996. Biology and conservation of forest fragments in the Brazilian Atlantic moist forest, p. 151-167. In: Schelhas, J. \& R. Greenberg (eds.). Forest patches, tropical landscapes. Washington, Island, $632 \mathrm{p}$.

Whitmore, T. C. 1990. An introduction to tropical rain forest. Oxford, Oxford University. 226 p.

Zucchi, R.; S. F. Sakagami; F. B. Noll; M. R. Mechi; S. Mateus; M. V. Baio \& S. N. Shima. 1995. Agelaia vicina, a swarm-founding polistine with the largest colony size among wasps and bees (Hymenoptera: Vespidae). Journal of the New York Entomological Society 103: 129-137. 